\title{
Demographic and behavioral profile of patients with optic medical indication of contact lenses
}

\author{
Perfil demográfico e comportamental de pacientes \\ com indicação médica óptica de lentes de contato
}

Fernanda Lika Tabushi ${ }^{1}$, Amanda Joekel Kassem¹, Vitor Yuto Mori Ota' ${ }^{1}$ Luciane Bugmann Moreira²

\begin{abstract}
Objectives: To assess the demographic and behavioral profile of patients with optic medical indication of contact lenses (CL) in a public hospital in Curitiba. Methods: Cross-sectional questionnaire study of patients who attended the contact lens service of the national health system (SUS) outpatient clinic from the "Hospital de Olhos do Paraná" between September 2 $2^{\text {nd }}, 2014$ and August 4", 2015. Results: Of the 69 people interviewed, $56.52 \%$ acquired CL. Of these, 55.07\% are between $20-49$ years old, $69.56 \%$ are women, $40.58 \%$ had finished high school and $36.23 \%$ earned a salary of 2 to 6 times the minimum wage. Rigid lenses prevailed, representing $66.67 \%$ of the total, with less than 8 hours of usage in $41.02 \%$ of the cases and discomfort during usage was assessed in $59 \%$. The cleaning of CL was done at the moment of insertion and removal in $87.18 \%$ of cases, and $71.8 \%$ used contact solution. High purchase cost was the main reason for not using CL for 70\% of patients who did not use this resource. Conclusions: Of the patients interviewed, $56.52 \%$ started using LC. Keratoconus was the main disease for which $C L$ were indicated. It was demonstrated in this study that patients in question have good guidance on handling and maintenance of LC. Despite the unquestionable advances in medical technology continue to occur the abandonment of the use of this feature mainly the cost and fear of handling. It is the responsibility of the expert clarify the benefits that patients with medical indication will have with the use of $L C$, as well as encourage their use.
\end{abstract}

Keywords: Contact lenses; Contact lenses/adverse effects; Keratoconus; Hygiene; Contact lens solutions

\section{RESUMO}

Objetivos: Avaliar o perfil demográfico e comportamental de pacientes com indicação médica óptica de lentes de contato (LC) em um hospital público de Curitiba. Métodos: Estudo transversal realizado através de questionário em pacientes atendidos no serviço de lentes de contato do ambulatório do SUS do Hospital de Olhos do Paraná, no período de 02 de setembro de 2014 a 04 de agosto de 2015. Resultados: Dos 69 entrevistados, 56,52\% fizeram LC. Destes, 55,07\% têm entre 20-49 anos, 69,56\% são mulheres, 40,58\% com ensino médio completo e $36,23 \%$ com 2 a 6 salários mínimos. Predominaram a lente rígida com $66,67 \%$, com menos de 8 horas de uso em $41,02 \%$ e desconforto durante o uso em $59 \%$. A limpeza das LC é feita ao colocar e ao retirar em $87,18 \%$ dos casos, com $71,8 \%$ utilizando solução própria para LC. Alto custo da compra foi o principal motivo do não uso de LC, com $70 \%$ dos pacientes que não fizeram uso desse recurso. Conclusões: Dos entrevistados, $56,52 \%$ iniciaram o uso de LC, sendo o ceratocone a doença mais indicada. Foi demonstrado nesse estudo que os pacientes em questão têm boa orientação quanto a manuseio e manutenção das LC. Apesar dos inquestionáveis avanços da tecnologia médica, continuam ocorrendo a desistência do uso desse recurso principalmente pelo custo e medo do manuseio. É responsabilidade do especialista esclarecer os benefícios que os pacientes com indicação médica terão com o uso de LC, assim como motivar o seu uso.

Descritores: Lentes de contato. Lentes de contato/efeitos adversos. Ceratocone. Higiene. Soluções para lentes de contato

\footnotetext{
${ }^{1}$ Departamento de Medicina, Universidade Positivo - Curitiba, PR, Brasil.

${ }^{2}$ Departamento de Oftalmologia, Curso de Medicina, Universidade Positivo - Curitiba, PR, Brasil.

Study carried out at Universidade Positivo and Hospital de Olhos do Paraná - HOP - Curitiba, Paraná (PR), Brazil.

The authors declare no conflicts of interests.

Received for publication 04/02/2016 - Accepted for publication 04/06/2016.
} 


\section{INTRODUCTION}

$\mathbf{T}$ The use of contact lenses (CL) increasingly gaining importance in the practice of ophthalmology. It is estimated that there are more than $140,000,000$ users of contact lenses in the world, being at least 2,000,000 of them in Brazil, according to estimates of Sociedade Brasileira de Lentes de Contato (SOBLEC) ${ }^{(1)}$.

While there are plenty of scientific articles related to unsuccessful adaptation of contact lenses in general and to complications caused by them ${ }^{(2-6)}$, there is few data in the literature regarding the conditions of use or not of CL specifically by patients with optical medical indication. There is a lack of consistent studies showing and justifying the lack of use of CL by these patients, since the CL are necessary to have good vision.

This research aims at evaluating the demographic and behavioral profile of patients with optical medical indication of contact lenses in a public hospital of Curitiba.

\section{Methods}

This cross-sectional study was approved by the Ethics and Research Committee of Universidade Positivo, under opinion number 1.105.118, and was carried out at Serviço de Lentes de Contato of SUS (Brazilian Single Health System) ambulatory at Hospital de Olhos do Paraná.

All patients who met the inclusion criteria received phone calls in an attempt to apply a questionnaire about the use of CL.

Inclusion criteria were: patients seen in the CL sector of SUS ambulatory at Hospital de Olhos do Paraná in the period from September 02, 2014 to August 04, 2015; and with optical indication due to medical reasons for the use of CL.

The inclusion criteria were: patients who did not answer the phone; those who were not found; and those who did not agree to answer the questions.

The questionnaire was applied after reading the informed consent (TCLE) and a verbal consent recorded, containing the following information: identification (name, age, and gender), education, monthly income, visual problem suggesting the use of contact lenses (CL), visual adaptation test, use or not of the CL, type of CL used, place of purchase of the $\mathrm{CL}$, frequency of use of the $\mathrm{CL}$, number of hours of use of the $\mathrm{CL}$, discomfort while using $\mathrm{CL}$, cleaning of the $\mathrm{CL}$, moment of cleaning of CL, product used to clean the CL, and reasons for not using CL.

Data was computed in an Excel spreadsheet (Microsoft Office, version 2013), and the percentages were calculated.

\section{ResULTS}

During the period from September 02, 2014 to August 04, 2015, 576 patients were attended in the ambulatory of contact lenses (CL) at Hospital de Olhos do Paraná (HOP).

The flowchart (Figure 1) below shows the relation of the patients who participated in the research.

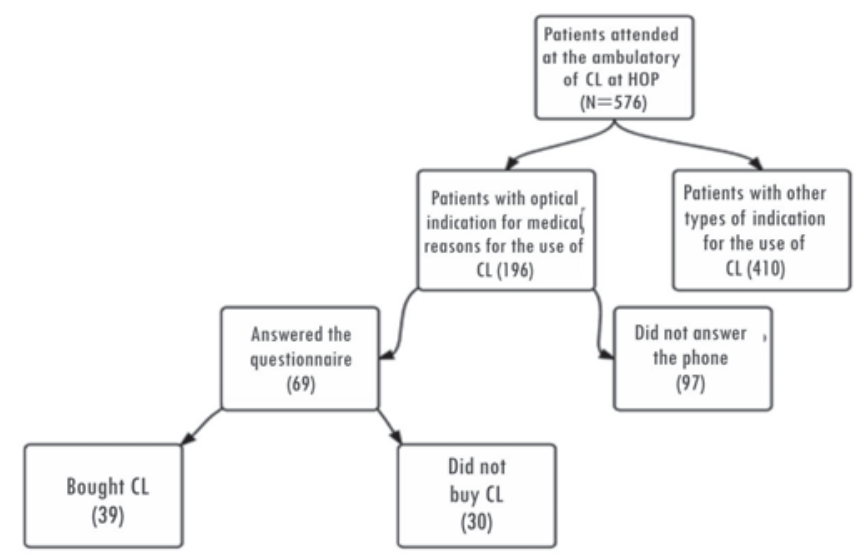

Figure 1: Flowchart of patients attended

The demographic data of the patients are shown in Table 1.

Table 1

Demographic data of the patients

\begin{tabular}{lrr}
\hline Age group & $\mathbf{N}$ & \% \\
\cline { 2 - 3 } $0-14$ & 7 & 10.14 \\
$15-19$ & 13 & 18.84 \\
$20-49$ & 38 & 55.07 \\
$50-64$ & 10 & 14.49 \\
$\quad>65$ years & 1 & 1.44 \\
Gender & & \\
$\quad$ Male & 21 & 30.43 \\
$\quad$ Female & 48 & 69.56 \\
Education & & \\
$\quad$ Illiterate & 2 & 2.89 \\
$\quad$ Elementary school & 17 & 24.64 \\
High school & 28 & 40.58 \\
$\quad$ Graduation & 22 & 31.88 \\
Monthly income & & \\
No income & 13 & 28.98 \\
Up to 1 minimum wage & 20 & 36.23 \\
2 a 6 minimum wages & 25 & 15.94 \\
$\quad>$ 6 minimum wages & 11 & \\
\hline
\end{tabular}

Table 2 shows data arranged about the contact lenses, showing the most prevalent visual problem.

Table 2

Data about prescription for contact lenses

\begin{tabular}{lclc}
\hline $\begin{array}{l}\text { Visual problem } \\
\text { suggesting } \\
\text { the use of CL: }\end{array}$ & $\begin{array}{c}\text { Bought } \\
\text { CL (39) \% } \\
\text { N(\%) }\end{array}$ & $\begin{array}{c}\text { Did not buy } \\
\text { CL (30) \% } \\
\mathbf{N}(\%)\end{array}$ & $\begin{array}{c}\text { Total } \\
(\mathbf{N = 6 9 )} \% \\
\mathbf{N}(\%)\end{array}$ \\
\hline Keratoconus & $17(24.63)$ & $8(11.59)$ & $25(36.23)$ \\
Irregular astigmatism & $6(14.13)$ & $2(4.71)$ & $8(11.59)$ \\
Corneal opacities & $0(0)$ & $1(1.44)$ & $1(1.44)$ \\
Anisometropia & $0(0)$ & $1(1.44)$ & $1(1.44)$ \\
Unilateral aphakia & $5(7.24)$ & $1(1.45)$ & $6(8.69)$ \\
Nystagmus & $1(1.44)$ & $0(0)$ & $1(1.44)$ \\
After penetrating & $5(7.24)$ & $3(4.35)$ & $8(11.59)$ \\
$\quad$ keratoplasty & & & \\
High ametropies & $5(7.25)$ & $14(20.28)$ & $19(27.53)$ \\
\hline
\end{tabular}


Of the 39 patients who make use of the CL, $66.67 \%$ use the rigid lens, whereas $33.33 \%$ (13) use the soft ones. Regarding the place of purchase of the lenses, $87.18 \%$ (34) bought them in the eye clinic, whereas $10.26 \%$ (4) acquired them in optical stores, and only one patient $(2.56 \%)$ ordered them online.

Regarding discomfort during use of CL, the time of cleaning and the type of product used for that, the results are shown in Table 3.

Among the CL users, 34 (87.18\%) responded that they use them daily, being removed only to sleep. Three patients $(7.7 \%)$ use them sporadically, and only two $(5.12 \%)$ make continuous use of the lenses. Regarding the number of hours of use, most patients use them less than 8 hours, whereas one third uses them for 9 and 16 hours.

Table 3

Profile of patients regarding the use of contact lenses

$\begin{array}{lrc}\text { Frequency of use of CL } & \text { N } & \text { (\%) } \\ \text { Daily, except to sleep } & 34 & 87.18 \\ \text { Continuous, without taking out to sleep } & 2 & 5.12 \\ \text { Sporadically } & 3 & 7.70 \\ \text { Hours of use of CL } & & \\ \text { Up to 4 hours } & 6 & 15.37 \\ \text { Between 5-8 hours } & 10 & 25.65 \\ \text { etween 9-16 hours } & 13 & 33.33 \\ \text { More than 16 hours } & 10 & 25.65 \\ \text { Discomfort while using CL } & & \\ \text { Yes } & 23 & 59.0 \\ \text { No } & 16 & 41.0 \\ \text { Cleaning of CL after use } & 39 & 100 \\ \text { Yes } & 0 & 0 \\ \text { No } & & \\ \text { Time of cleaning of CL } & 3 & 7.70 \\ \text { While putting } & 2 & 5.12 \\ \text { While removing } & 34 & 87.18 \\ \text { When putting and removing } & 0 & 0 \\ \text { Daily, even without using } & & \\ \text { Product used for cleaning the CL } & 11 & 28.20 \\ \text { Saline } & 28 & 71,80 \\ \text { Solution for lenses } & 0 & 0 \\ \text { Other types }\end{array}$

CL: contact lenses

As shown in table 4, of the respondents who didn't make use of contact lens, $70 \%$ (21) justified it with the high cost of purchase, and a patient claimed to be afraid of the handling. The eight remaining patients responded having other reasons, among them the non-adaptation to the use of CL.

\section{Table 4}

Patients who don't use contact lenses

\begin{tabular}{lrc}
\hline Reason & N & \% \\
\hline Afraid to use & 1 & 3.33 \\
High cost & 21 & 70.0 \\
Never being interested & 6 & 20.0 \\
Not adapted & 2 & 6.67 \\
\hline
\end{tabular}

\section{Discussion}

During the study period of approximately one year, 576 patients were attended at Serviço de Lentes de Contato of SUS (Brazilian Single Health System) ambulatory at Hospital de Olhos do Paraná, and 166 of them had optical indication for medical reasons to use CL. Of them, 69 answered the questionnaire proposed, and the other 97 patients were not found, many of them due to their phone numbers being outdated, which justifies the small sample number.

In the present investigation, the demographic data is similar to those observed by other authors both in Brazil and in other countries, women were predominant, the age was between 20-49 years, and with complete high school ${ }^{(4,6-10)}$.It is suggested that this finding is due to the fact of women, especially the younger, give more value the aesthetic appearance and contact lenses having optical, occupational, sports and cosmetic advantages ${ }^{(11)}$.

Regarding the economic aspect, our study showed that most of patients $(36.23 \%)$ had monthly income between 2 to 6 minimum wages. A study conducted in 1999 in the city of Curitiba $^{(12)}$ pointed out that the population has an average monthly expense of $3.9 \%$ of the family income directed to health assistance in the acquisition, maintenance and care of glasses and contact lenses, corresponding to an average 0.4 minimum wages per year. Converting those numbers into the current minimum wage ( $\mathrm{R} \$ 788.00)$, and considering the latest Household Budget Survey ${ }^{(13)}$, there is no significant difference regarding the part of the minimum wage annually spent on the acquisition, storage and maintenance of glasses and contact lenses.

In 2005, a study carried out at the Santa Casa de Misericordia do Rio de Janeiro showed that the most prevalent optical indication for medical reasons was anisometropia with $54 \%$ of the cases, followed by keratoconus with $44 \%$. On the other hand, this study showed that keratoconus was the visual pathology with more prescriptions for use of contact lens, with $36.23 \%$ of indications, and anisometropia had only $1.44 \%$. As the glasses do not correct the patient's visual acuity anymore, the use of CL is indicated and the main form of treatment of keratoconus, which justifies the high incidence of this disease as an optical medical indication for the use of CL. In some cases of anisometropia, the glasses can have good adaptation ${ }^{(11,14)}$.

Culkierman and Boldrim (2005) showed that of the total cases adapted, $64.51 \%$ were with rigid lenses and $35.49 \%$ with soft lenses. This finding is similar to the present study, in which $66.67 \%$ of patients use the rigid lens and $33.33 \%$ use the soft type. It can be explained by the advantages that rigid lenses offer to the quality of vision, eye health, ease of care and durability, although soft lenses are initially more comfortable ${ }^{(11)}$.

The CL were acquired in eye clinic by $87.18 \%$ of patients, in the optical store by $10.26 \%$, and only one patient $(2.56 \%)$ ordered them online. These results are similar to those found in the literature, such as in the publication of Ghanem et al., which showed that $85.8 \%$ acquired the CL with the ophthalmologist, whereas $11.4 \%$ bought them in the optical store $\left({ }^{15}\right)$. This study shows that buying online is less frequent here than in the United States, where the Center for Disease Control and Prevention ${ }^{(7)}$ showed that $66.9 \%$ acquired CL at doctor's office, $10.4 \%$ in the optical store, and $20.8 \%$ online.

Different from the literature, this research shows that $33.33 \%$ use it an average of 9 and 16 hours a day, while Lui et al. calculated that $86.9 \%$ use CL for more than 8 hours a day, being 
the average usage between 8 and 16 hours per day $(75.4 \%)^{(8)}$. A large percentage of users still exceed 12 hours a day, longer than the recommended time, increasing the risk of complications.

It is known that it is essential to clean the CL after their removal not to impregnate bacteria and relevant daily deposits. The literature shows a percentage of $67.1 \%$ cleaning them at the right time, whereas the study carried out at Hospital de Olhos do Paraná studied that in $92.3 \%$ of cases $^{(9)}$. Regarding the solution used to clean the CL, $71.8 \%$ of patients use a solution specific for CL, and $28.2 \%$ make use of saline, the same way that Lui et al. also identified that $78 \%$ use multipurpose solution, and $18 \%$ use saline ${ }^{(8)}$. The multipurpose solutions increase the life of CL and help in disinfection, besides being more convenient for patients, facilitating the adherence regarding the conservation of the lens ${ }^{(16)}$.

Oliveira et al. did not have the same result. They mention that saline was the most often used product to clean the contact lenses, even more than multipurpose solutions ${ }^{(10)}$.

The saline has no disinfectant activity and is subject to contamination, even when kept in the refrigerator. All contact lens, regardless of being rigid or soft, disposable or conventional, must go through a process of maintenance including daily cleaning, disinfection and removal of protein deposits ${ }^{(16)}$. Thus, considering that these procedures as recommended prophylaxis for infection, it can be seen that the care carried out by participants of this research, even by those with less education, are similar to the study of Lui et al. ${ }^{(8)}$. It shows that the patients studied have good guidance regarding maintenance of the CL, but they need to be constantly advised. During each appointment, the patient should have asked about their behavior in relation to $\mathrm{CL}$, and be always reminded of the conduct to be followed with verbal and written guidance.

This research shows that $59 \%$ of users feel uncomfortable while using CL. According to the Tear Film \& Ocular Surface Society (TFOS), contact lens discomfort is a condition characterized by ocular adverse feelings related to the use of lenses, resulting from the reduction of the degree of compatibility between the contact lens and the ocular environment, which may lead to decreased time of use or discontinuation of it ${ }^{(17)}$. The cause of the discomfort may be due to the properties of the CL, such as the type of material used and the durability of the lens. It can also be due to the inherent characteristics of the patient, such as age, gender and race, as well as ocular and systemic diseases. Systemic diseases and medications can interfere with production of tear film and the integrity of the ocular tissue and its components. The external environment may even influence the comfort of the patient on the use of CL. The exposure of the eye to variations of temperature and humidity, as well as adverse lighting and excessive visual information coming from electronic media, changes the reflection of blinking and eye lubrication, causing discomfort ${ }^{(17)}$.

Of the 30 respondents who did not use contact lens, even with medical indication, $70 \%$ justified not using them due to the high cost in the purchase. Other patients had reasons as fear of handling, lack of interest and adaptation to the use of CL. The reason stated seems important due to the income of respondents being between 2 and 6 minimum wages.

Excuses as lack of interest and fear of handling the $\mathrm{CL}$ show failure of the doctor-patient relationship due to the lack of motivation and guidance regarding this product. In a publication of 1966 in the Journal of Medical Education, $67 \%$ of the doctors attributed the lack of adherence to the non-cooperative personality of the patient, whereas only $26 \%$ thought the doctor would be responsible for the situation ${ }^{(18)}$. It is the specialist's responsibility to explain the benefits that patients with medical indication will have with the use of CL, as well as motivate them for the use of this product ${ }^{(14)}$. One should pay attention to the fact that the patient's ability of understanding is influenced not only by the clarity or complexity of the information, but also by the biopsychosocial aspect involving them. Also, the perception of their own behavior by the patients is crucial for the success in adapting to $\mathrm{CL}$ and preventing complications.

Before starting any adaptation with contact lenses, it is important to assess the degree of motivation of the patient, their hygiene conditions and ability to follow the recommendations proposed. Unmotivated patients tend to have little correlation to the methods of care prescribed for the CL, increasing the chances of complications.

The success of using CL depends on factors such as: careful patient selection, appropriate adaptation, regular control, cleaning and storage care with the correct use of the solutions, user education, and medical guidance in a clear and constant way.

\section{CONCLUSION}

This study showed that patients studied have good guidance regarding handling and maintenance of contact lenses.

Despite the undeniable development in medical technology, discontinuation of use of this product continue to happen, mainly due to the cost and fear of handling.

It is the specialist's responsibility to explain the benefits that patients with medical indication will have with the use of contact lenses, as well as encourage their use.

\section{ReferenCES}

1. Lipener C. Jornal Oftalmoloìgico Jota Zero. 2012; (nov/ dez):37.[citado 2015 Dez 15]. Disponível em: http:// www.cbo.com.br/novo/medico/pdf/jo/ed146/completo-146.pdf.

2. Pritchard N, Fonn D, Brazeau D. Discontinuation of contact lens wear: a survey. Int Contact Lens Clin. 1999;26(6):157-62.

3. Young G, Veys J, Pritchard N, Coleman S. A multi-centre study of lapsed contact lens wearers. Opthal Physiol Opt. 2002;22(6):516-27.

4. Richdale K, Sinnott LT, Skadakl E, Nichols JJ. Frequency of and Factors Associated With Contact Lens Dissatisfaction and Discontinuation. Cornea. 2007; 26(2):168-74.

5. Chalmers RL, Begley CG. Dryness symptoms among an unselected clinical population with and without contact lens wear. Contact Lens Anterior Eye. 2006; 29(1):25-30.

6. Schlanger JL. A study of contact lens failures. J Am Optom Assoc. 1993; 64(3):220-4.

7. Cope JR, Collier SA, Rao MM, Chalmers R, Mitchell GJ, Richdale $\mathrm{K}$, et al. Contact Lens Wearer Demographics and Risk Behaviors for Contact Lens-Related Eye Infections: United States, 2014. MMWR Morb Mortal Wkly Rep. 2015; 64(32):865-70.

8. Lui GA, Leça RG, Rehder JR, Netto AL. Avaliação do nível de conhecimento quanto ao uso de lentes de contato entre os estudantes de medicina da Faculdade de Medicina do ABC. Rev Bras Oftalmol. 2010; 69(6):361-6.

9. Vidotti VG, Kamegasawa A. Perfil dos alunos usuários de lentes de contato do curso de Medicina da Universidade Estadual Paulista - UNESP - Botucatu. Arq Bras Oftalmol. 2006;69(2):197-20. 
10. Oliveira PR, Kara-José N, Alves MR, Temporini ER. Observância da orientação médica pelo usuário de lentes de contato. Arq Bras Oftalmol. 2004; 67(4):607-12.

11. Cukierman E, Boldrim E. Perfil do Setor de Lente de Contato da Santa Casa de Misericórdia do Rio de Janeiro. Rev Bras Oftalmol. 2005; 64(2):77-82.

12. Castellano AGD, Moreira LB, Kaimoto TT, Moreira H. Aspectos socioeconomicos em pacientes portadores de viìcios de refrac'aPo. Arq Bras Oftalmol. 1999; 62(6):697-700.

13. Coordenação de Trabalho e Rendimento/IBGE. Despesas, rendimentos e condições de vida. Pesquisa de Orçamentos Familiares 2008-2009. Rio de Janeiro; 2010.

14. Moreira SM, Moreira H, Moreira LB. Lentes de contato. $3 \mathrm{a}$ ed. Rio de Janeiro: Cultura Médica; 2004.

15. Ghanem CC, Ghanem RC, De Bertoli GW, Yamazaki ES. Comportamento e características de usuários de lentes de contato entre estudantes universitários da área de saúde. Arq Bras Oftalmol. 2000; 63(2):123-27.
16. Lipener C, Ray CBM. Sistemas atuais de cuidados e manutenção de lentes de contato. Arq Bras Oftalmol. 2008;71(6):9-13.

17. Nichols JJ. Contact Lenses 2015. Contact Lens Spectrum. 2016; 31(1):18-23.

18. Davis MS. Variations in patient's compliance with doctors' orders: analysis of congruence between survey responses and results of empirical investigations. J Med Educ. 1966; 41(11):1037-48.

Corresponding author:

Fernanda Lika Tabushi

Av. Três Marias, 1175. Casa 41. São Bráz, Curitiba - PR 82310-000

E-mail: fernanda_lika@hotmail.com 